\title{
Climate Change, Copenhagen and Psycho-social Disorder
}

\author{
Jonathan Paul Marshall, University of Technology, Sydney
}

Given the obvious dangers of climate change, the failure of the 2009 Copenhagen

Climate Conference requires social theorists to investigate reasons for the breakdown that go beyond pointing out the fear of change, describing denial, talking of conflict between particular power-blocks, demanding justice, or positing that the ruling class is determined to make money at the expense of the ecological system and their own survival. If we are to talk of 'interests' we need to talk of how people come to know their interests, and how they frame the world so as to make those interests seem real and possible. In taking this step we move into the interwoven realms of cosmology and psychology. I assume that human social dynamics grows out of the nature of human being and cannot be completely abstracted away from that being. At the same time I want to be attentive to matters arising around 'disorder,' so that disorder is not considered a residue, a pathology, or something to be bypassed as inessential. Disorder is at the heart of our problem and needs to be part of our theory. This essay looks at responses to climate change as psycho-social responses mediated through myth and disordered networks. It begins with an account of editing a book on climate change (Marshall 2009), and takes the insights from this process to an analysis of the Copenhagen conference and its aftermath. Within the international process, I particularly investigate whether myths of Justice provide useful templates for behaviour.

\section{Disorder}

Disorder, as implied by the early writings of Mary Douglas (1969), is that part of the

PORTAL Journal of Multidisciplinary International Studies, vol. 8, no. 3, September 2011.

Special issue details: Global Climate Change Policy: Post-Copenhagen Discord Special Issue, guest edited by Chris Riedy and Ian McGregor.

ISSN: 1449-2490; http://epress.lib.uts.edu.au/ojs/index.php/portal

PORTAL is published under the auspices of UTSePress, Sydney, Australia. 
world which slides out of our ego-based conceptual categories, and that we then recognise or label as bad. This includes both internal and external orders and disorders-which can appear to mesh together. Disorder that is repressed does not go away; it returns and disrupts our hold on order. What is labelled as disorder always has troubling internal resonance: it becomes a source and object of projections of what we deny or repress in ourselves (in Jungian terms our 'shadow'), and contributes to the process of those selves and the varied (and conflicting) systems they are part of. ${ }^{1}$

Social theory immersed in this view does not discard disorder, rubbish, exceptions, aberrations, or individual oddities. When compared to other disciplines, anthropology's strength has been its interest in those things which others have ignored-magic, gifts, kinship, and so on. Here this welcoming of discards is simply extended, and I attempt to refuse the violence that is done to the material through explanations which order through excessive simplification; turning mess into perfect structures; reducing variants to a single story; looking for simple abstract models or core elements; or building ideal types and discarding everything which does not fit. With sufficient ingenuity anything can be made to resemble almost anything else, but the differences and disorders may remain significant.

A disorder sensitive social theory would not be just a typology of disorders, although the attempt might teach something. It would not aim for simplicity but for complexity; for not making the discard taboo, but knowing it probably would do so anyway. Perhaps it might become symbolic-poetic itself, in order to make the lack of clarity clear. Each attempt would be a different 'way in' and self confessedly incomplete. However, it would recognise that disorder and resistance to ordering is a vital part of psychosocial dynamics, just as culture conflict is a vital living part of culture.

\section{A metaphor}

A 'thrum' is the fringe of warp threads left on a loom after the cloth has been cut off; the unwoven ends of warp thread remaining on the loom when the web has been removed; a short or loose end of thread projecting from the surface of a woven fabric; the odd bits of waste; the knots and negatives on the back of the carpet that make the decorations. Without the discard or underneath thrum there is no weaving. Afterwards

\footnotetext{
${ }^{1}$ This is necessarily a brief schematic outline of the relevant psychology. For more detail see Marshall (2009).
} 
thrums can be ordered or felted together and used elsewhere. Waste can serve a purpose. Socially a thrum is a company or body of people (or animals), a crowd, a bundle (of arrows); it suggests mess. Oddly it could once mean 'magnificence' and 'splendour.' It can also mean careless playing or a smooth sound. Thrum is paradoxical—a linkage in rhythm and resonance-it implies the background sound, the decaying resonance of piano notes as they shift into their own musics - the interactive space hanging between notes which is usually discarded in the rush to the next notes. It implies that the momentary makes the moment, the waste makes the product and that the order there is not necessarily an order underlying anything. Such an order is just another thrum, elsewhere.

\section{Climate change as a symbolic event}

Climate change might be ideal for our purpose in exploring thrums and sociopsychology given that it is multifaceted, falling into many contested categories, and a subject for inner and outer life. Climate is already highly symbolic and can encapsulate our inner storm, frosts, droughts, floods, fires or desert. It is already part of our inner lives and dreams; we cannot feel dispassionately about it. We respond deeply to these events and they map both our inner awareness and our unconsciousness. These psychological resonances cannot be stripped away from the reality of climate change, however much we might try; they disorder pure 'rationality' and provide its driving thrum.

We are in the middle of several major pollution and ecological crises—declines in arable land, over-population, the sixth great extinction, and transgenic escapes for example-yet it is climate change that has taken hold of the imagination, becoming the centre of argument-perhaps because it has such symbolic resonances. It is, as LeviStraus remarked in another context, 'good to think with' (1967).

Perhaps the first thing to say about climate change is that it is big. It cannot be conceived in its entirety. At the least, it involves the mysteries of: the world, nature, social and political action, morals, our psychology, the future, death, and the distribution of suffering. It joins together a whole series of otherwise disparate existential issues and problems. As such it is precisely the kind of 'thing' that becomes 'numinous' and becomes caught up in the mythic narratives that we use to make sense of the world, such as 'justice' or 'apocalypse.' 
Furthermore, change in climate is inherently disordering of previous orders. Indeed previous orders might be the waste thrum not yet discarded. There is no known state we can pretend is equilibrium. Taking disorder seriously and not thrusting it aside, we can say that climate change and the sense of disorder it encapsulates do produce psychological disordering. We can start to trace this particular disorder, not as an aberration, which might otherwise not be happening, but in itself, or in its selves.

Climate change resonates with social and psychological disorder, provoking ego breakdown or increased rigidity, and threatens organisational breakdown. It is usually defended against in relatively predictable ways, given particular social backgrounds and mythic vocabulary. This defence may further reinforce the disordering and its effects.

This paper attempts to tease out some of the threads, knowing that they are not the weaving, yet that without them the weaving could not come to be, and to relate this to both the process of editing a collection of essays on depth psychology and climate change and then the Copenhagen Conference and its aftermath.

\section{The book}

The book, Depth Psychology, Disorder and Climate Change (Marshall 2009) grew out of a panel on climate change organised by Sally Gillespie, then President of the Jung Society of Sydney. The panel was successful enough for the Society Committee to try and persuade more people to contribute and turn the event into a collection of essays.

I sent around a call for papers to people who were suggested to me, and whom I knew through the Society or through Gillespie. The call was enthusiastically received and nearly everyone who was approached stated they should easily be able to find something to write about. We moved out of the local Jungian circle as people were suggested by other people. Some people who gave talks to the Society were also approached, perhaps too many people: it resulted in a messy book. We had network and contact based sociality in action. Tenuous threads became temporarily concrete; yet the network was never closed, in the sense that communication never proceeded amongst all participants — or, if it did, I was not included. Probably most contact, but not all, was via email or attempted, but missed, email. Sometimes, the weaving was through people visiting, or conversations occurring quickly and hesitantly 'elsewhere' in passing. The network was never clear; people saw knots rather than patterns. This was a temporary, 
semi-contingent, network, woven out of other ties - in other words the network existed for a function and was likely to break when the function was fulfilled or failed. This temporariness is common in contemporary social formation. It was not an ordered network, nor a resilient network, simply the thrum of the potential book, without which the book would not exist and of which the book is the trace; itself a thrum of this passing network. I would suggest that this temporary thrumming, (edges, passing knots and resonance) is the way we generally act together in contemporary western society, while nostalgically or projectively (paranoically) thinking others act in a more orderly, coordinated, or rigid manner.

This formation had a temporary hub in myself and the Jung Society. This hubbing had something of a radial formation. Some of the contacts continued in other forms later, or carried on, in a slightly transformed manner the loose ties previously existing. Thrums that persisted perhaps — of which new orders were made and then left no trace? It faded in and out like a wave on other waves.

Although it is tempting to claim networks are orders, they are often at best temporary, hidden orders, easily broken by even one person. The knot holding it all together gets cut and the weaving unravels. The more central the knot or the person the more it unravels, or the more it separates into other parts. Networks are hard to rescue once broken. They need endless maintenance and repair to keep existing, so as not to fragment into individual threads, or rather for the threads not to be caught in other projects and pulled apart. Gaps and forgetting occurred, people who should have been asked were not; the consequences never certain. It would seem especially that networks are always unravelling themselves as well as being unravelled by others. In Copenhagen the powerful also found that sociality slips away, hanging into nothingness. Power relations are a network, with pathways and patterns which are easily triggered, yet always unstable, so we can never tell where the unravelling will begin.

In this weaving we also have the shifting thrums of sense-making, of bodily stolidity, symbols and psychology—a base perhaps, or just a bass line, figured but improvised, depending on what comes next from the others thrumming along.

Then the book network started to get complicated in a repetitiously disordered manner - the interference became the thing or, again, the thrum that made the process. 
Most of the contributors seemed concerned about climate change. Many of them showed, what seemed to me, a surprising familiarity with official reports and public science-more surprising still given the 'anti-science,' poetic and religious bent of a fair number of those contributors. The contradictions, or edges of disturbance, emerge continuously. Many of the contributors, including myself, repeatedly felt themselves being called to write, but blocked as to the actual writing in many different ways. In some cases people had to drop out as other things took greater precedence, or their lives were consumed by chaos and other networks. This is, of course, what you expect. Nobody ever finds editing a collection is smooth, especially with a one-year deadline, but we composed a collection of people who were aware of the importance of the issues they were supposed to conceive, but many of whom found speaking or writing close to impossible. They were often stuck, and stuck quite badly. Promising starts flattened into halting ventures. Vagueness, even to readers familiar with Jungian discourse, was common. There were clear gaps in argument. Repeated corrections and changes of direction were presented. Our ideas often appeared disordered, disconnected, dislocated, disoriented, disjointed, disrupted, disorganised and sometimes disengaged. The chaos supposedly located within the external world leaked into a chaos of the internal world and was not easily separated out. It constituted us as individuals socially engaged and sharing. 'Internal' and 'external' mirrored and perhaps magnified each other. Yet how else can conception occur, other than through symbols, the thrum not yet discarded as people reached out, or the symbols reached out of them, to deal with the disordering and the unknown they were immersed in?

Frequently contributors ignored my request not to list the facts of climate change. I felt we already had enough books about 'the facts.' However, some people felt compelled to write at length about how climate change was appalling, or to tell readers, or themselves, that the situation was urgent. They listed facts. Quite often this listing had no discernable connection with the rest of their paper. I have since been told this urge for listing and condemnation (or 'moral clarity') is common in climate change projects and I, certainly, have heard people give academic presentations in which they repeat these facts and their anger about them, without ever reaching what they had declared to be the point of their papers. It is as if, in the face of horror, or visceral uncertainty, people feel compelled to recap what is known, as if this will clear something up, or reassure us-as if the repetition will give us an order in which to act. The chaos slides 
away, under the litany of what we call reality. Or perhaps the repetition reinforces the ego by its nature; the ego dwelling in repetition, it reweaves or restates. Listing becomes ritual, which serves to let ourselves ride through chaos, or state yet again where we are, and state that we are right and good. Perhaps it prevents us confronting the turmoil within and allows us to see the turmoil as outside? The crisis induces frantic attempts to solve the issue within the framework we already have, and perhaps to condemn others. The binary seems to be marked here. Whichever 'side’ we are on, we have to be both right and righteous - and while 'side' does not have to be binary, it usually falls that way for us. Politics ideally has two sides, so does football; in business it tends to be 'us' versus the world — which it would seem already stacks 'the world' up as an enemy, to preserve the order that orders us.

Morality slides in, in other ways as well. As writers, people involved in the project often seemed swayed by morals or common sense, knotting beneath and making linkages between symbols. Sometimes the argument seemed to be that climate change is bad and therefore we should change our behaviour (and this from depth psychologists-if only therapy was that easy). Sometimes the argument seemed to be that as climate change was bad then our behaviour might change automatically.

These arguments and repetitions, by naming the iniquity, could be seen to be attempts at creating unity both in ego and group simultaneously, by finding or making an evil or an immoral other, and expelling it by making a scapegoat and turning it to thrum. Once the scapegoat, whether internal or external, was gone then all would be well, at least until the pattern perishes. Morals are an ordering (which often prevents exploration) and which require things to fall out of them to be condemned and prove those morals worthwhile: this is the pattern of justice. However, with morals the psyche could pretend to harmony, the ego would be temporarily safe, at least until the ritual could be performed again. But each time is different, and the cutting of the weaving to finish off, leaves remains behind-it is not whole cloth, our disorder is not gone.

The moral argument when deployed by people convinced that climate change is real, often implies that those who deny climate change are deliberate and often conscious deniers, people who take a stand against social change, or who lie in favour of capital, or just want to have fun, or something. I am deeply uncomfortable about this kind of argument, as despite the ease of seeing the deniers of climate change as destroying us 
through their greed, or protecting their profit and status, it seems to me, that if you read their writings and listen to their speeches, that the 'bad guys' are also consumed by panic, incoherence, uncertainty and repetition. Frequently everyone is searching for order and justice where none can exist.

\section{Justice}

Oppositions to capitalist orders of climate change are frequently woven together in terms of Justice. There is the 'climate justice movement,' for example, and this is not just an opposition but, as we shall see, a not inessential knot of the Copenhagen negotiations, which helped them unravel. Justice is a myth that 'justifies' one’s moral superiority over others, and allows the projection of 'evil' onto others. In the myths of States and Empires, Justice occurs when the divine sets aside its proclaimed love, compassion or benevolence and engages in retribution. It excludes the unjust and often destroys them; something which might not be possible if we recognise our connections, or don't want to authorise war. Justice can also allow one to continue what one does, as: 'Everyone is more or less a bad guy because everyone contributes to climate change, and controlling it goes to the heart of every national economy’ (M’Gonigle 2009).

Concepts of climate justice seem inadequate for the project of reducing climate emissions. Let us take two examples of arguments from Australia. First, Barnaby Joyce, a National Party member, before the talks began:

Penny Wong [Australian Climate Change Minister] is arguing countries like China should be entitled to produce more emissions and set their own targets because they are an emerging economy. If that is the case, then why can't parts of rural and regional Australia, with their developing economies, be allowed the same concession? (Joyce 2009)

Second, Tony Abbott, Leader of the Liberal Party and the Federal Opposition, in December 2009: 'Now we have about one per cent, or a little over, of global emissions. We could reduce our emissions to zero and China would make up the difference in less than a year given its increasing rate of emissions' (Abbott 2009). Similarly, it was reported that the G77 nations, did not want binding emissions targets for themselves, only for the developed nations, 'arguing that they need to keep access to cheap, plentiful fossil fuels to haul themselves out of poverty’ ('UN Climate Talks’ 2009). Labor Primeminister Kevin Rudd responded: 'Go to the future, if we the developed countries became carbon neutral tomorrow let me tell you the combined impact of China and 
India into the medium term future would be huge' (Rudd 2009b). Something likewise stated by Jonathan Pershing, the US deputy special climate change envoy, who said that China, India, Mexico, Brazil, and Indonesia 'will be responsible for 97 percent of the future growth in emissions' (Corn 2009).

There is nothing particularly illogical about these positions, and they are making claims about justice and about fairness. Emissions can be both just and unjust depending on where you are. If you look at China and India's actual emissions and potential emissions, then they constitute a large proportion of the actual global emissions. If you look at emissions per head then they are quite small. Further, if you regard emissions as essential for relieving poverty then, by objecting to their emissions, you are also condemning their people to poverty. Yet, if they don't make cuts then other people in small island states and in Africa will probably suffer. Ideas of Justice cannot get you out of this position as there are competing and conflicting ideas of what is just and what is fair. Justice can also be incapacitating and lead to positions demanding purity, which can imply that as everything must be done to be effective, nothing can be done. An AP report in the Sydney Morning Herald quoted NASA Scientist James Hansen’s argument that:

dealing with climate change allowed no room for political compromises. "This is analogous to the issue of slavery faced by Abraham Lincoln or the issue of Nazism faced by Winston Churchill ... On those kind of issues you cannot compromise. You can't say let's reduce slavery, let's find a compromise and reduce it 50 per cent or reduce it 40 per cent." ('Global Warming "Godfather", 2009) $)^{2}$

Everyone has different notions of justice, but each surely thinks that they are just and the others criminal. Justice, indeed, requires a criminal other-which is always likely to make some people nervous and attack in return. By demanding a scapegoat, it also panders to our own 'shadows,' our own ego defences and blindness. We also have to ask 'who it is that determines what is just or not? Who is to enforce it? What kind of hierarchy of violence will make that enforcement work? How are we going to adjudicate between competing claims? Is it just for developing countries to have their chance to pollute? And so on. It might be possible to argue that, in the same way as it is easier to get agreement on what constitutes disorder than it is to get agreement on what constitutes order because disorder can occur in many more ways, it might be possible to get people to agree on what is unjust. However, such agreement will not change the

\footnotetext{
${ }^{2}$ Besides, slavery was not ended all over the world at one time; it was reduced in parts.
} 
disagreement about what is fair and just, what time frames should be involved, what the continuum of emissions should be, the relationship between development and emissions, or the relationship between current and ideal emissions. It simply enables us to eliminate states of affairs that are not actually probable or existent. For example, we might agree it would be unjust if an already highly polluting country (however we separate high from low polluters) doubled its greenhouse pollution in less than two years, when all other countries had decreased their emissions. Such elimination does not remove conflict from justice, the thrum of our own repressions, or the need for enforcement.

Justice demands that all worldviews and social formations are uniform, or else it risks being unjust; yet without recognising that forms of life conflict, it cannot deal with reality. Choosing justice as the rubric for action, is possibly better than choosing the myth of apocalypse, because apocalypse immobilises altogether, but it does not let us deal with the mess of climate or power relations. Justice requires a unity and coordination which has not yet been woven, and cannot be built out of the clash without risking war.

\section{Copenhagen itself}

Before we even get to the likely impossibility of anyone weaving an all-encompassing plan out of the Copenhagen meeting, we need to look at the complexity of the patterns of participation - the mess, the knots and thrum without a pattern. This account is something of a broken patchwork of presentation but it expresses the reports; and the expression of that disorder is more necessary than use of unexamined assumptions that the truth is whole and hidden.

There were a total of 194 registered State parties to the conference, with 10,583 delegates. There were another two observer States, 900 registered observer organisations with a further 13,482 participants and another 3,221 media people (UNFCCC 2010: 2). Among the observers were the World Trade Organisation and the World Bank. This was reduced from the numbers who wanted to attend: 'The UNFCCC secretariat revealed last night that 34,000 people had applied for accreditation to the meeting, taking place in a conference centre which only holds 15,000' (McCarthy 2009a). Although background negotiations and alliances had been building up over the year and people have relatively clear ideas of what can be done (even if they differ), the 
provisional timetable is confronting in the amount to be done (see UNFCCC 2009).

Just to give some further idea of the mix; the official Norwegian delegation included parliamentarians, public servants, diplomats, scientists, business people, unionists, environmental activists, members of charities, and unmarked individuals (UNFCCC 2009: 154ff). Coherence was not always that marked even within state delegations.

The recognised power blocks at the Conference were:

- The G-77, a loose coalition of 131 “developing nations,” including China, India, Afghanistan, Indonesia, Sudan, Cuba, Papua New Guinea and Saudi Arabia.

- The 41 Industrialised (Annex 1) countries. Annex 1 was defined in earlier treaties. It not only includes the USA, Australia, the UK, Germany, Japan, Russia etc, but Liechtenstein, Bulgaria, Estonia and Romania and other relatively poor small states. At the United Nations Earth Summit in Rio de Janeiro in 1992, it was agreed that only these countries had to reduce emissions.

- The 38 Small Island Developing States who make up about 20 percent of the UN general assembly, with another 14 non-UN members.

- The least developed countries bloc.

- And, the OPEC block, which could be expected to oppose any limits on selling oil.

- Some sources also mention an African climate-negotiating group headed by Ethiopia.

On top of this there were simultaneous international activist forums, the most notable being the Klimaforum09, again with a roughly joined patchwork of players. George Monbiot (2010) commented:

I came back from the Copenhagen climate talks depressed for several reasons, but above all because, listening to the discussions at the citizens' summit, it struck me that we no longer have movements; we have thousands of people each clamouring to have their own visions adopted. We might come together for occasional rallies and marches, but as soon as we start discussing alternatives, solidarity is shattered by possessive individualism.

There was also the so-called Climate Group, which focused on a meeting of regional governments with at least 60 premiers, governors and ministers, featuring Al Gore, Prince Charles and Helen Clark. This meeting asked the main meeting to recognise that 'up to 80 per cent of mitigation and adaptation actions are implemented at the subnational level' and awarded the 'inaugural State Leadership Award for Action on Climate Change' to Arnold Schwarzenegger (Posner 2009). A trade union delegation led by Sharan Burrow, then president of the Australian Council of Trade Unions (ACTU), claimed to represent '168 million workers in 154 countries,' and attempted to lock in 'labour standards and good quality jobs' (Baggio 2009). Finally, there was also a parallel meeting, of climate sceptics. As Ian Plimer (2009) writes: 
Two Copenhagen climate conferences took place last week.... The conference I attended used science to understand the past, present environments and pollution. This was essentially unreported because journalists are scientific illiterates and this is not sensational news ... The other conference, the UN's political conference, is about the redistribution of your money through sticky fingers.

\section{The tearing web}

While there are 'ecological' connections between all these people, there are not going to be 'human' connections; the sheer numbers and potential differences involved have to be acknowledged. There are few simple coherent networks here. These are knots without a visible tapestry. So not only do people face the kind of psycho-social disruption we have discussed, but it is likely that groups will fragment, networks dissolve, and alliances will fracture, making little basis for mutually agreed justice.

For example, there are obvious overlaps in block membership; the categories are not coherent or mutually exclusive. India and China are not easily classified as 'developing' or powerless when compared to some Annex 1 countries. China is somewhere between the second and third largest economy in the world with a GDP of close to US\$8 trillion, Tuvalu’s GDP is US\$15 million (Borofsky et al. 2009). Estonia, an Annex 1 country has a GDP of less than US\$22 billion. Annex 1 countries don’t have much in common, or many historical unities, but the most obvious conflict amongst them over reduction targets was between the USA and the EU. Conflicts also manifested between relatively poor States with large forests (Papua New Guinea and Indonesia) and those without, as REDD proposals are of little use if you have no industrial emissions, limited agricultural emissions or no forests. The small island states argued that they faced destruction with the treaties being proposed, and broke with China and India. Venezuela and Bolivia, seemed to consider themselves a separate independent Marxist block, but Venezuela is an oil producer. Categories like 'West' and 'the rest,' or 'North' and 'South,' don't begin to capture the complex patterns of alliance and fracture manifested here or, perhaps more importantly, the potential change in the world's power balance. The USA has in less than twenty years gone from being the world's only unchallengeable superpower, to a troubled player amongst many.

Furthermore, countries themselves were not coherent. Members on both sides of the US Senate were openly opposed to restrictions on US activities. The conservative Opposition in Australia opposed the Government's scheme for carbon reduction as did the Greens. There was a vocal and popular 'climate sceptic' movement in the USA, 
Australia and the UK supported by much of the mainstream media, which was largely hostile to any action at all; it can be seen in any online newspaper article of the period that allows comments. Frequently sceptics argue that action hurting the economy would hurt the poor and cost jobs, and thus, by implication, be unjust.

There was no web at the conference, only potentials and broken patterns. One of the problems that arose repeatedly was the problem of sovereignty. Climate change cannot be solved nationally and thus it changes the relationships between states. India and China objected strongly to the idea of their emission cuts being inspected, just as much as the USA objected to other states putting limits on them. There is a suspicion of unjust freeloading by others, which implies that generous actions would be unfairly exploited. The same fragility exists elsewhere; even in an era which has celebrated neo-liberalist 'free trade,' it is notable that multi-party trade talks have continually broken down, and that most trade agreements have been bilateral, cutting down the number of participants and limiting complexity. Even these, such as the 2004 Australia-United States Free Trade Agreement, have frequently been attacked as giving too much leeway to one or the other side, and overpowering local legislations. Categories of national self and national ego are challenged by international regulation. Incidentally the World Trade Organisation's Seventh Ministerial Conference in Geneva, took place in the weeks before Copenhagen, with the focus on increasing world trade and hence on increasing carbon emissions from transport. Conflict and incoherence reign everywhere-this is part of the politics that must be dealt with.

Confusion is not only present in the interactions. Process is also confused. Thus in one article from 6 December environmentalist Bill McKibben argued that climate change was unlike other political problems in that it could not be solved by incrementalism:

\footnotetext{
the adversary here is not Republicans, or socialists, or deficits, or taxes, or misogyny, or racism, or any of the problems we normally face-adversaries that can change over time, or be worn down, or disproved, or cast off. The adversary here is physics ... physics doesn't just impose a bottom line, it imposes a time limit. This is like no other challenge we face because every year we don't deal with it, it gets much, much worse, and then, at a certain point, it becomes insoluble. (McKibben 2009a)
}

A mere four days later, perhaps faced with deadlock, he compared climate change to the fight for health care in the USA, and said that something is better than nothing (McKibben 2009b). 


\section{Demands}

I do not want to reiterate the science here, as that is well known. What is significant is that the Small Island States captured a large amount of publicity for their plight, and for demands that temperature rises should be kept to less than 2 degrees Centigrade and $\mathrm{CO}_{2}$ be restricted to 350 parts per million or less. This was never going to be agreed to by the big emitters, such as the USA and China. One commentator wrote:

The dispute is fundamental because the amount of greenhouse gases already in the air condemns
the world to an increase of at least 1.5 degrees. Meeting the victims' demand, therefore, would
mean either stopping all emissions immediately, which would be impossible, or reducing them
much faster than expected and finding a way of getting carbon dioxide out of the air. (Lean 2009)

We are arguing as the world weave tears.

\section{Conference moods}

The conference moods and conflicts display the psychological processes. Geoffrey Lean stated that the conference 'started in a more optimistic frame of mind than any I can remember in four decades of similarly tricky negotiations' (Lean 2009). Interviewed on the ABC on 8 December, Sydney Morning Herald Correspondent Marian Wilkinson said there 'is a hell of a lot of energy here and there is a buzz around this conference. There's no doubt about that. The optimism/pessimism is very difficult to judge because, frankly, people swing quite wildly between the two extremes' ('Copenhagen Climate Change Summit’ 2009).

A day or so later Time Magazine reported that: 'Already, grinding diplomacy and criticism have overshadowed the good feelings and pageantry of the opening day of the summit’ (Walsh 2009). Australian Climate Change Minister Penny Wong agreed with the statement on 10 December that 'the atmosphere that you have flown into is not promising ... the conflict between developing and developed nations and even within the developing nations themselves, a lotta harsh words going around?' ('Penny Wong Live’ 2009). Afterwards Todd Stern, the US State Department Climate Change Envoy, said that the summit was 'a snarling, aggravated, chaotic event' (Watts et al. 2010).

Richard Black of the BBC noted that the Danish chief negotiator was sacked as a result of conflict between Danish Premier Lars Lokke Rasmussen and the Climate Minister Connie Hedegaard. 'This destroyed the atmosphere of trust that developing country negotiators had established with Mr Becker’ (Black 2009). The Danes, probably 
worried that there was too much to get through, hurried people along, leaving players feeling their position had not been taken into account: 'China's chief negotiator was barred by security for the first three days of the meeting ... This was said to have left the Chinese delegation in high dudgeon' (Black 2009). Rasmussen also offended people by implying he could not trust some delegates: 'Criticism of [Rasmussen] has been backed by China, India—and Brazil, which Denmark has viewed as an ally’ (Rothenberg et al. 2009).

This fragmentation of expected alliances and organisation could be expected to produce paranoia-like analysis. The release of emails hacked from the East Anglia Climatic Research Unit, which allowed climate sceptics to claim climate science was 'cooked,' led UN officials to claim the hackers were probably paid to undermine the Copenhagen summit (Totaro 2009). Similarly, a day after the conference started, there was a leaked document: 'a secret draft agreement worked on by a group of individuals known as 'the circle of commitment' - but understood to include the UK, US and Denmark [which] has only been shown to a handful of countries since it was finalised this week' (Vidal 2009a). The document was supposed to indicate that the agreement had already been stitched up, and that the conference was to hand power to the 'rich countries.' Fury was expressed at the document. One anonymous diplomat said: 'Clearly the intention is to get Obama and the leaders of other rich countries to muscle it through when they arrive next week. It effectively is the end of the UN process' (Vidal 2009a). On the other hand it was reported that: 'U.S. delegate Jonathan Pershing played down the implications of the document. “There is no single Danish text, there are many Danish texts.” He went on, “If there was no Danish text, I would be appalled [since the delegates' ...] job is to bring something to the table' (Stone 2009).

Marian Wilkinson reported further fears:

We've been told by negotiators here that there is a fear from the Chinese and the Indians. They fear that the verification measures put in place could be used against them, especially by the US Congress, also perhaps by some of the European parliaments, to impose carbon tariffs on them; that this will be used as a weapon to slug them in the international trade sphere ('Crunch Time' 2009).

India’s Environment Minister, Jairam Ramesh, accused Australian Prime Minister Kevin Rudd of lying about his position on climate change and pulled out of a meeting with Australian Climate Change Minister Penny Wong. She reportedly said that 'she did 
not know why Mr Ramesh pulled out of the crucial meeting. "You will have to ask him”" (Wilkinson 2009). Ramesh claimed he had been too busy. Ramesh also called Australia an ayatollah for wanting a single treaty to bind everyone (Wilkinson 2009). In other talks, members of the G77 walked out to protest about the apparent abandonment of the Kyoto Protocol, and Australia 'then shut down the talks on emission cuts for rich countries’ (Wilkinson 2009). About the same time, Lumumba Di-Aping, a Sudanese diplomat who was the official chief negotiator for the G77 group, said: 'The message Kevin Rudd is giving to his people, his citizens, is a fabrication, it’s fiction' (Alberici 2009). After the event, a journalist asked Penny Wong if she got 'the feeling that India is really boasting that it has sort of put one over the larger nations?' (Wong 2009).

Reports of the final day of negotiation suggest that there was a clash between China and the USA, in particular, and that there was also an attempt to generate a sub-conference to make things more controllable. A Guardian report claimed that after 'eight draft texts and all-day talks between 115 world leaders, it was left to Barack Obama and Wen Jiabao, the Chinese premier, to broker a political agreement’ (Vidal 2009b). The Independent reported that the 'day's most remarkable feature was a direct and unprecedented personal clash between ... Barack Obama, and ... Wen Jiabao’ (McCarthy 2009b). The reporter explains the clash as stemming from Obama's public insistence that the Chinese should allow their announced cuts to be inspected, and that without such verification an agreement was worthless. Wen sent subordinates to all further meetings and Obama was deeply annoyed (McCarthy 2009b). If this were the case, then this was not a new demand. Many Annex 1 countries wanted everyone to make cuts and have them verified; it could seem the Chinese were 'seeking' to be insulted and insulting.

People were not happy with the process of the final day. Journalist George Monbiot said:

Obama went behind the backs of the UN and most of its member states and assembled a coalition of the willing to strike a deal that outraged the rest of the world. This was then presented to poorer nations without negotiation: either they signed it or they lost the adaptation funds required to help them survive the first few decades of climate breakdown. (Monbiot 2009)

Richard Black of the BBC, agreed that the deal was struck behind closed doors: 'The end of the meeting saw leaders of the US and the BASIC group of countries (Brazil, South Africa, India and China) hammering out a last-minute deal in a back room as 
though the nine months of talks leading up to this summit, and the Bali Action Plan to which they had all committed two years previously, did not exist' (Black 2009). The most detailed account of part of the final day was given by Mark Lynas (2009), the climate advisor to Mohamed Nasheed, the President of the Maldives. He said about 5060 people were in the room, and that Wen Jiabao did not attend. The Chinese insisted that the previously agreed upon 2050 targets be taken out of the deal: “"Why can't we even mention our own targets?” demanded a furious Angela Merkel. Australia's prime minister, Kevin Rudd, was annoyed enough to bang his microphone.' (Lynas 2009).

The Chinese further insisted that statements that emissions should peak by 2020 be removed:

[T] he Chinese delegate [also] insisted on removing the 1.5C target so beloved of the small island states and low-lying nations who have most to lose from rising seas. President Nasheed of the Maldives, supported by [Gordon] Brown, fought valiantly to save this crucial number. "How can you ask my country to go extinct?” demanded Nasheed. The Chinese delegate feigned great offence - and the number stayed, but surrounded by language which makes it all but meaningless. (Lynas 2009)

Later on, Kevin Rudd said:

At about one o'clock this morning in Copenhagen, after seventeen hours straight of negotiation today, we agreed on a Copenhagen Accord on climate change. This was agreed in a negotiating group of about twenty-five nations ... This last round of negotiations with that group began at 11 pm last night. It ran through to three this morning, with myself in attendance, and then Penny Wong remained through the night. I resumed at 8am this morning and we have just concluded at lam the next day. It has been a long day ... The truth is, as of twenty four hours ago, these negotiations stood at a point of complete collapse. (Rudd 2009c)

With this level of exhaustion, it is improbable that anyone was thinking straight. Obama left immediately, ironically and officially because of weather issues, but leaving distanced him, or attempted to distance him, from the mess of the involvement and the potential insecurity of his position, when not backed by Congress. Networks fractured, and perhaps had little chance of holding the threads of coherent constructive power in these psychosocial circumstances; unthreading was more likely.

\section{Aftermath}

John Sauven, executive director of Greenpeace UK, said: 'The city of Copenhagen is a crime scene tonight, with the guilty men and women fleeing to the airport' (Vidal 2009b). Lumumba Di-Aping, chairman of the G77, and thus notionally a supporter of continuing Chinese emissions, stated that the agreement 'is asking Africa to sign a 
suicide pact, an incineration pact in order to maintain the economic dependence of a few countries. It's a solution based on values that funnelled six million people in Europe into furnaces’ (Batty 2009).

Indian and Chinese representatives tried to explain the breakdown in unity, and their power, in the G77 by conspiracy:

"There have been some efforts to deliberately divide us," one of the senior Chinese negotiators, Qingtai Yu told the BBC. "We have seen such moves here and this is nothing new" ... An Indian negotiator echoed the same message, adding, "In fact some of the poor countries have been threatened (by some developed countries not to toe the line of the G77) and we know there will be many such efforts" ... "The allegation that we are trying to divide them is baseless and incomprehensible," said Karl Falkenberg, a representative of the European Commission. "You can see how divided they are on issues like average temperature rise and blaming us for that state does no good.” (Khadka 2009)

The Guardian reported that a Chinese government think tank reinforced Chinese conclusions after the talks: “"A conspiracy by developed nations to divide the camp of developing nations [was] a success,” it said, citing the Small Island States’ demand that ... Brazil, South Africa, India, China ... impose mandatory emission reductions’ (Watts et al. 2010).

Mark Lynas, climate advisor to the President of the Maldives, said in response:

It's astonishing that this document suggests the Chinese really believe the absurd conspiracy theory that small island states were being played like puppets by rich countries. The truth is that the small island states and most vulnerable countries want China and its allies to cut their emissions because without these cuts they will not survive. Bluntly put, China is the world's No1 emitter, and if China does not reduce its emissions by at least half by mid-century, then countries like the Maldives will go under. (Watts et al. 2010)

I'm not entirely convinced that UK Prime Minster Gordon Brown was not right to say: 'This is the first step we are taking towards a green and low-carbon future for the world, steps we are taking together. But like all first steps, the steps are difficult and they are hard' (Batty 2009). Perhaps too much was expected, and expectations also disrupted the process.

In March 2010 it was reported that:

Many countries resented that it had been thrashed out and imposed on them outside the formal UN negotiation process. But 114 countries have backed up their initial support by formally associating themselves with the accord and 74 have submitted targets to cut or slow greenhouse gas emissions. Nearly 80 per cent of the world's emissions are included. (Morton 2010a) 
In June 2010 claims were made that China's leaders were preparing 'the ground to exceed China's pledge to reduce carbon emissions intensity by 40 to 45 per cent by 2020” (Garnaut 2010). Advice from the Australian Department of Climate Change suggested that 'steps being taken by China might be equivalent to Australia cutting emissions by 25 per cent” (Morton 2010b). China cannot be accused of simple reluctance and resistance; things are much messier than that. In terms of comparative complexity we need to remember that the Kyoto accord was initially signed as a framework in 1997. The rulebook was completed in 2001. It took effect in February 2005. It was ratified by Australia only in 2008, and was never agreed to by the USA.

Reports of the Tianjin conference, which appeared as I wrote the first draft of this essay (October 2010), suggest that the fracture, weaving and unravelling, the discarding and the felting, the ordered and the contingent, the distress and cries of injustice, continue to have play and will not fall into a simple order. Yet out of the chaos has come something, the thrum has become felt. Perhaps it is not useful, and perhaps it will be unthreaded, perhaps it did not matt thoroughly enough, but at the same time this disorder and dismembering is part of the politics and part of the social process and cannot be ignored by attempting to render what happened simple and coherent.

\section{Conclusion and suggestions}

This paper has attempted to show that disorder is inherent in climate change and our psychosocial responses to it. With climate change, our certainties, alliances and social categories breakdown, as do the ways we organise our egos and our realities. The metaphor of thrum allows play with the intertwined mess and order, and shows that disorder cannot be ignored. Networks, personal and political tend to be fragile. Use of power disorders as much as it orders. Old guiding myths such as Justice are no longer useful for ordering this course of events. Justice fails because it seeks a scapegoat, demands elimination of disorder and requires a uniformity, agreement and enforcement that cannot be present.

On the other hand, disorder can be a sign of something neglected, of the unconscious or the unknown, as well as of a burgeoning creativity that can look like vandalism. Depth psychology suggests that it is useful to listen to the disorder rather than discard it. It suggests that, with listening, this disorder can be symbolically synthesised with one's ordering, so as to produce a new state that allows the person, or group, to better deal 
with their problems. This renders disorder, no longer simply disorder but something symbolically conceivable, or recognisable, which is neither obstacle nor discard. Disorder is no longer trash, but incorporated, transformed, as part of the pattern. Depth psychology does not claim to know what this new order is in advance; that has to be formed, and uncertainty accepted during this process. The new order does not mean that there is no longer disorder. Disorder is always present because our conceptual apparatus is always limited, and there is always something left over. Just as we cannot describe anything completely in a finite period of time, so we cannot order everything. We can only work within the limits of what is orderable at the time, hoping for a minimum of relevant or repressed disorder. We move from one disorder to the next, which hopefully will test out as more adaptive and more moral.

Rather than demanding fairness and justice, perhaps we can ask all who are concerned to act now, to cut back emissions, to find new lives and morals which apply to them rather than are demanded of others. This is not denying the social power in a group of people moving together, but a wariness of a group that exists against another. Such a group will create this 'other' and is likely to unconsciously become it. Similarly we can ask people to respect the disorder of reality; not to demand or rush to an order which is not present, but rather to seek to listen to the thrumming, however much it appears to be part of the background, the mess, or the breakdown. We may likewise need to learn how to deal with disordered, fragmentary and fragile networks, as opposed to ordered institutions, and to keep them unravelling long enough to serve their momentary purpose.

Calling for ourselves and our leaders to listen to disorder rather than demanding certainty and ultimatums, may seem as impractical as calling for Justice, but it may also be less destructive and more productive of new solutions which are not locked into our current ways of being and relations of power.

\section{Reference List}

Abbott, T. 2009. 'Interview with Fran Kelly.’ Radio National, 16 December. Online, available: http://parlinfo.aph.gov.au/parlInfo/download/media/pressrel/AYHV6/upload_binary/ayhv60.pdf;fi leType=application/pdf [Accessed 9 October 2010].

Alberici, E. 2009, 'Copenhagen Negotiator Accuses Rudd of Lying,' ABC News, 16 December. Online, available: http://www.abc.net.au/news/stories/2009/12/16/2772948.htm [Accessed 9 October 2010]. 
Baggio, G. 15 December 2009, 'History in the Making, Slowly,' Sydney Morning Herald, 15 December. Online, available: http://www.smh.com.au/environment/climate-change/history-in-the-makingslowly-20091214-ksdp.html [Accessed 9 October 2010].

Batty, D. 2009, 'Copenhagen reaction: delegates speak,' The Guardian, 19 December. Online, available: http://www.guardian.co.uk/environment/2009/dec/19/copenhagen-reaction-delegates-speak [Accessed 9 October 2010].

Black, R. 2009, ‘Why Did Copenhagen Fail to Deliver a Climate Deal?’ BBC News, 22 December. Online, available: http://news.bbc.co.uk/2/hi/science/nature/8426835.stm [Accessed 9 October 2010].

Borofsky, Y. Nordhaus, T. \& Shellenberger, M. 14 December 2009. 'The End of 'Developing Countries,' Breakthrough Insitute, 14 December. Online, available: http://thebreakthrough.org/blog/2009/12/the end of developing countrie.shtml [Accessed 9 October 2010].

'Copenhagen Climate Change Summit Kicks Off' 2009, 7.30 Report, ABC, 8 December. Online, available: http://www.abc.net.au/7.30/content/2009/s2765603.htm [Accessed 9 October 2010].

Corn, D. 2009, 'Who Needs a Binding Climate Treaty?' Mother Jones, 8 December. Online, available: http://motherjones.com/politics/2009/12/us-who-needs-binding-climate-treaty [Accessed 9 October 2010].

'Crunch Time in Copenhagen,' 7.30 Report, ABC, 14 December. Online, available: http://www.abc.net.au/7.30/content/2009/s2771588.htm [Accessed 9 October 2010].

Douglas, M. 1969, Purity and Danger: An Analysis of Concepts of Pollution and Taboo. Routledge and Kegan Paul, London.

Garnaut, J. 2010, 'China to Cut Energy Use and Emissions,' Sydney Morning Herald, 18 June. Online, available: http://www.smh.com.au/business/china-to-cut-energy-use-and-emissions-20100617yjuv.html [Accessed 9 October 2010].

‘Global Warming ‘Godfather' Goes Cold on Copenhagen’ 2009, Sydney Morning Herald, 3 December. Online, available: http://www.smh.com.au/environment/climate-change/global-warminggodfather-goes-cold-on-copenhagen-20091203-k7ds.html [Accessed 9 October 2010].

Joyce, B. 2009, 'Bangkok Climate Change Talks Fail: Precursor to Failure in Copenhagen. 09-October2009.' Media Release. Online, available: http://www.barnabyjoyce.com.au/Newsroom/MediaReleases/tabid/74/articleType/ArticleView/arti cleId/968/Bangkok-Climate-Change-Talks-Fail-Precursor-to-failure-in-Copenhagen.aspx [Accessed 9 October 2010].

Khadka, N. 2009, 'Developed Countries Accused of Dividing Developing Ones,' Climate Change Media Partnerships, 12 December. Online, available: http://www.climatemediapartnership.org/reporting/stories/developed-countries-accused-ofdividing-developing-ones/ [Accessed 9 October 2010].

Lean, G. 2009, 'Copenhagen: The Lessons We are Being Forced to Learn,' Telegraph.co.uk, 12 December. Online, available: http://www.telegraph.co.uk/earth/copenhagen-climate-changeconfe/6791053/Copenhagen-the-lessons-we-are-being-forced-to-learn.html [Accessed 9 October 2010].

Levi-Strauss, C, 1967, The Savage Mind. University of Chicago Press, Chicago.

Lynas, M. 2009, 'How Do I Know China Wrecked the Copenhagen Deal? I was in the Room.' Guardian, 22 December. Online, available: http://www.guardian.co.uk/environment/2009/dec/22/copenhagen-climate-change-mark-lynas [Accessed 9 October 2010].

Marshall, J. P. 2009, Depth Psychology, Disorder and Climate Change. Jungdownunder Books, Sydney.

McCarthy, M. 2009a, 'Greenhouse Gas Cuts Just “Token Gestures,”' The Independent, 7 December. Online, available: http://www.independent.co.uk/environment/climate-change/greenhouse-gascuts-just-token-gestures-1835499.html [Accessed 9 October 2010]. 2009b, 'Obama’s Climate Accord Fails the Test,' The Independent, 19 December. Online, available: http://www.independent.co.uk/environment/climate-change/obamas-climate-accordfails-the-test-1845090.html [Accessed 9 October 2010].

McKibben, B. 2009a, 'Why Politics-As-Usual May Mean the End of Civilization,' The Huffington Post, 6 December. Online, available: http://www.huffingtonpost.com/bill-mckibben/why-politics-asusual-may_b_382013.html [Accessed 9 October 2010]. 2009b, 'Obama’s Climate Position: A Lie Inside a Fib Coated with Spin,’ Mother Jones, 12 December. Online, available: http://motherjones.com/environment/2009/12/obamas-climateposition-lie-inside-fib-coated-spin [Accessed 9 October 2010].

M’Gonigle, M. 2009, ‘Against Copenhagen: Why We Need to "Lose” at this Week's Climate Summit If We are to Win the Fight against Global Warming,' The Tyee, 6 December. Online, available: 
http://thetyee.ca/Opinion/2009/12/06/CopenhagenContradictions/ [Accessed 9 October 2010].

Monbiot, G. 2009, 'If You Want to Know Who’s to Blame for Copenhagen, Look to the US Senate,' The Guardian, 21 December. Online, available:

http://www.guardian.co.uk/commentisfree/2009/dec/21/copenhagen-failure-us-senate-vestedinterests [Accessed 9 October 2010].

2010, 'After this 60-year Feeding Frenzy, Earth Itself has Become Disposable,' The Guardian, 4 January. Online, available:http://www.guardian.co.uk/commentisfree/2010/jan/04/standard-ofliving-spending-consumerism [Accessed 9 October 2010].

Morton, A. 2010a, 'Climate Can-do in Cancun?,' The Age, 27 March. Online, available: http://www.theage.com.au/environment/climate-change/climate-cando-in-cancun-20100326r33g.html [Accessed 10 December 2010]. 2010b, “Australia's wake-up call on emissions target”, Sydney Morning Herald, 30 November. Online, available: http://www.smh.com.au/environment/climate-change/australias-wakeup-call-onemissions-target-20101129-18dxb.html [Accessed 9 October 2010]

'Penny Wong Live from Copenhagen,' 7.30 Report, ABC, 10 December. Online, available: http://www.abc.net.au/7.30/content/2009/s2768309.htm [Accessed 9 October 2010].

Plimer, I. 2009, 'The Copenhagen Charade,' ABC 'Unleashed.' Online, available: http://www.abc.net.au/unleashed/28144.html [Accessed 9 October 2010].

Posner, R. 2009, 'Emissions Terminator Shows How to Inspire a Crowd,' Sydney Morning Herald, 17 December. Online, available: http://www.smh.com.au/environment/climate-change/emissionsterminator-shows-how-to-inspire-a-crowd-20091216-kxlo.html [Accessed 9 October 2010].

Rothenberg, M., Aagaard, M., \& Andersen, E. O. 2009, 'Løkke har problemer med topmøde-formen,' politiken.dk, 18 December. [translated via Google translate] Online, available: http://politiken.dk/klima/klimapolitik/article862988.ece [Accessed 9 October 2010].

Rudd, K. 2009a, ‘Transcript of COAG Press Conference,’ 7 December. Online, available: http://pmrudd.archive.dpmc.gov.au/node/6380 Accessed 9 October 2010]. 2009b, 'Transcript of interview. ABC AM,' 14 December. Online, available: http://pmrudd.archive.dpmc.gov.au/node/6395 [Accessed 9 October 2010]. 2009c, 'Transcript of joint press conference with the Minister for Climate Change, Copenhagen,' 19 December. Online, available: http://pmrudd.archive.dpmc.gov.au/node/6403 [Accessed 9 October 2010].

Stone, D. 2009, 'The 'Danish Text' Disrupts Copenhagen: What You Need to Know,' Newsweek, 8 December. Online, available: http://www.newsweek.com/blogs/the-gaggle/2009/12/08/the-danishtext-disrupts-copenhagen-what-you-need-to-know.html [Accessed 9 October 2010].

Totaro, P. 2009, 'UN Blames Professional Hackers’ Sydney Morning Herald, 8 December. Online, available: http://www.smh.com.au/environment/climate-change/un-blames-professional-hackers20091207-kffs.html [Accessed 9 October 2010].

'UN Climate Talks: The Key Players,' The Independent, 30 November, Online, available: http://www.independent.co.uk/environment/un-climate-talks-the-key-players-1831330.html [Accessed 9 October 2010].

UNFCCC 2009, Overview Schedule, 8 December. Online, available: http://unfccc.int/files/meetings/cop_15/application/pdf/overview_schedule_cop15.pdf [Accessed 9 October 2010]. 2010, List of participants. Part One. Parties (A-O). FCCC/CP/2009/INF.1 (Part 1). Online, available: http://unfccc.int/resource/docs/2009/cop15/eng/inf01p01.pdf [Accessed 9 October 2010].

Vidal, J. 2009a, 'Copenhagen Climate Summit in Disarray after “Danish Text’ Leak,' The Guardian, 8 December. Online, available: http://www.guardian.co.uk/environment/2009/dec/08/copenhagenclimate-summit-disarray-danish-text [Accessed 9 October 2010].

2009b, 'Low Targets, Goals Dropped: Copenhagen Ends in Failure.' The Guardian, 19 December. Online, available: http://www.guardian.co.uk/environment/2009/dec/18/copenhagen-deal [Accessed 9 October 2010].

Walsh, B. 2009, 'Copenhagen’s Real Challenge: Technology to Meet the Targets,' Time, 9 December. Online, available: http://www.time.com/time/specials/packages/article/0,28804,1929071_1929070_1946649,00.html [Accessed 9 October 2010].

Watts, J., Carrington, D., \& Goldenberg, S. 2010, ‘China’s Fears of Rich Nation 'Climate Conspiracy’ at Copenhagen Revealed,’ The Guardian, 11 February. Online, available: http://www.guardian.co.uk/environment/2010/feb/11/chinese-thinktank-copenhagen-document [Accessed 9 October 2010]. 
Wilkinson, M. 2009, 'India Lashes Out at Climate Stance’ Sydney Morning Herald, 17 December. Online, available: http://www.smh.com.au/environment/climate-change/india-lashes-out-at-climate-stance20091215-kuof.html [Accessed 9 October 2010].

Wong, P. 2009, ‘Transcript of Press Conference Adelaide 23 December 2009.' Australian Parliament House, Canberra. Online, available: http://parlinfo.aph.gov.au/parlInfo/download/media/pressrel/DFKV6/upload binary/dfkv60.pdf;fil eType $=$ application/pdf\#search $=\% 2200 \mathrm{AOU} /$ ReporterId00AOU|SpeakerId00AOU\%202000s\%20m edia\%22 [Accessed 9 October 2010]. 